\title{
Siyasi Katılım, Tutum ve Davranıșlarda Kadın ve Erkek Arasındaki Farklılıklar
}

\author{
Differences between Women and Men in Political Participation, Attitude and Behaviour
}

Cihan ERTAN*

$\ddot{O}_{z e t:}$ Siyasi davranış ya da siyasi katılım sadece oy verme veya siyasi bir partiye üyelik olarak ele alınamaz. Çünkü siyasi davranış, dolaylı eylemler (yoksullara, yaşlılara, evsizlere yardım programlarına katılmak gibi) aracılığıyla da kendini gösterebilmektedir. Başka bir ifadeyle, eylemin sosyal ve ekonomik bir amacının olması koşuluyla söz konusu eylem, siyasal bir eylem olarak kabul edilebilir. Genel olarak, kadınların ve erkeklerin siyasete katılımları arasında farklılıklar söz konusudur ve bunların, bireysel tercihlerin bir sonucu olduğu düşünülse de daha çok toplumda var olan toplumsal cinsiyet eşitsizliğinin siyasi katılım üzerindeki etkileridir. Bu çalışmada siyasete katılım bağlamındaki bu davranışsal farklılıklar, toplumsal cinsiyet eşitsizliğiyle ilişkili bir şekilde tartışılarak, kadınlar ve erkeklerin siyasi davranışları arasındaki farklılıkların temel nedenleri aydınlatılmaya çalışılacaktır.

Anahtar Sözcükler: Siyasi davranış, toplumsal cinsiyet, siyasi katılım, davranışsal farklılıklar

Abstract: Political behavior or participation can not be treated as only to vote or political party membership. Because political behavior might be emerging by means of indirect practices such as participation to support programs for poor, elder and homeless people. One practice, in other words, could be accepted as a political practice if it has an economical and social purpose. There are some distinctions, in general, between women and men regarding political participation. Although these distinctions are perceived as the result of individual preferences, rather they are, mainly, the influences of the existing gender inequality in society on political participation. In this study, behavioral distinctions concerning political participation will be discussed in relation gender inequality and also the primary reasons of differences of political behavior between men and women will be illuminated.

Keywords: Political behavior, gender, political participation, behavioral differences

Siyasi katılım ve tutum, genel olarak siyasi davranış bağlamında kadınlar ve erkekler arasındaki herhangi bir farklılığın söz konusu olup olmadığı sosyal bilimlerde tartışılan bir konudur. Bu tartışmalar, genel olarak toplumsal cinsiyet eşitsizliklerini merkeze aldığından, söz konusu bu eşitsizliklere ışık tutması açısından büyük bir önem arz etmektedir.

Kadınlar ve erkeklerin, siyasi davranışlardaki farklılıkları ortaya koymak, toplumsal cinsiyet dışında da konuyu etkileyen çok fazla faktör olduğundan ve siyasi davranışa yol açan süreçlerin karmaşık yapısından dolayı oldukça zordur. Diğer bir zorluk da siyasi davranışın ne olduğunun tanımlanmasında yatmaktadır. Bu bağlamda ilk olarak, siyasi davranışın ne olduğunu ortaya koymanın, atılacak ilk adım olması gerektiği ileri sürülebilir.

Siyasi katılım ya da davranış pek çok şekilde ortaya çıkabilir. Siyasal davranış, sosyo-ekonomik konum, kır-kent ayrımı, eğitim seviyesi ve toplumsal cinsiyet gibi birçok değişken temelinde ele alınmaktadır. Dolayısıyla siyasal katılım ya da davranıș, basit bir biçimde, oy verme

\footnotetext{
* Arş. Gör., Akdeniz Üniversitesi, Edebiyat Fakültesi, Sosyoloji Bölümü, Antalya, cihanertan1@gmail.com
} 
eylemi değildir (Sarıbay, 1994). Siyasi davranışı sadece oy verme ve siyasi bir partiye üyelik olarak ele almak, konuya yönelik eksik ve sorunlu bir bakışı beraberinde getirecektir. Çünkü siyasi davranış, dolaylı eylemler (yoksullara, yaşlılara, evsizlere yardım programlarına katılmak gibi) aracılı̆̆gıla da kendini gösterebilmektedir. Başka bir ifadeyle, eylemin sosyal ve ekonomik bir amacının olması koşuluyla söz konusu eylem, siyasal bir eylem olarak kabul edilebilir (Wintringham, 2005'den aktaran Kart, \& Güldü, 2009, 98). Sarıbay (1994), siyasi davranış geniş bir boyutta ele alınması gerektiğini şu cümlelerle ifade etmektedir:

\begin{abstract}
“...siyasal katılma, her şeyden önce, bireyin kendi iradesi doğrultusunda meydana getirdiği davranışlarla siyaseti etkileme olayıdır, bu bakımdan seçimlerde oy verme, katılmanın sadece bir boyutunu oluşturur. Bir başka deyişle, siyasal katılma seçimlerde oy vermekten ibaret değildir" (Sarıbay, 1994, 37).
\end{abstract}

$\mathrm{Bu}$ çalışma, siyasal davranışı toplumsal cinsiyet özelinde tartışmaktadır. Başka bir ifadeyle amaç, toplumsal cinsiyetin, siyasal davranış üzerindeki potansiyel etkilerini incelemektir. Ancak unutulmamalıdır ki toplumsal cinsiyet tek başına siyasi davranış bağlamında kadın - erkek arasındaki farklılığını açıklamada yetersizdir. Toplumsal cinsiyet ve diğer değişkenler arasındaki ilişki ve bunların, kadın ve erkeklerin siyasi davranış ya da katılımlarındaki farklıklarıyla olan ilişkisi de göz önünde tutulmalıdır.

\title{
Toplumsal Cinsiyet Temelinde Siyasi Katılımı Etkileyen Faktörler
}

Politik güç içindeki toplumsal cinsiyet eşitliği, eskisinden farklı olarak, endüstrileşmiş demokrasilerde son 50 yil içinde oldukça büyük bir gelişme göstermiştir. Ulusal parlamentoya artık daha fazla kadın girebilmekte ve daha fazla kadın kendi uluslarının devletlerinde yönetici konumunda bulunabilmektedir (Coffe, \& Bolzendahl, 2010, 318). Türkiye'de, bir vatandaş olarak kadınların da erkeklerle aynı haklara sahip olmasını yazılı olarak bildiren ve 1926'da yürürlüğe giren Türk Medeni Kanunu, kadın hukuku açısından bir devrim niteliğindedir (Koyuncuoğlu, 1998, 58). Bunu takiben kadınlara, 1930 yılında yerel seçimlerde, 1934 y1lındada genel seçimlerde seçme ve seçilme hakkı tanınmıştır (Arat, 1998, 51). Şüphesiz ki kadınların siyasi katılımı, bu günlere kadar artarak devam etmiştir. Artık çok daha fazla kadın hem yönetim birimlerine seçilmekte ve seçmekte ya da politik amaçlar taşıyan eylemler sergilemektedir.

Bütün bu gelişmelere karşın, yapılan bazı araştırmalar (Ranaboldo, \& Solana, 2008; Ennaji, 2010; Shvedova, 2005; Gönül Birliği Kültür ve Yardımlaşma Derneği, 2009), kadınlar ve erkekler arasında, siyasi katılım açısından farklılıklar olduğunu ortaya koymaktadır. Buna göre, kadınlar erkeklere göre daha az siyasi davranışlarda bulunmaktadırlar. Bazı araştırmacılar, siyasi katılım açısından toplumsal cinsiyet temelindeki farklılı̆̆ın, yaş ve eğitime göre daha az olduğunu ileri sürmektedirler. Ancak, siyasi katılım, demokrasilerin önemli bir parçası olduğundan, siyasi katılımdaki toplumsal cinsiyet eşitsizlikleri, toplumun bütününde var olan toplumsal cinsiyet temelindeki bir tabakalaşmayı yansitabilir (Coffe, \& Bolzendahl, 2010, 318).

Coffe ve Bolzendahl (2010), daha önce de ifade edildiği gibi, siyasi katılımın "geleneksel" olarak kavramsallaştırılan oy verme, bir kampanyada çalışma, bir parti organizasyonuna katılım gibi direkt olarak seçimle ilgili eylemlerle sınırlandırılamayacağını ileri sürmektedir. Kart ve Güldü (2009), siyasi katılımın sadece oy verme ve siyasi bir partiye üye olma olarak algılanmasının bizleri, kadınların katılımının fazlaca yetersiz kaldığı sonucuna götüreceğini ifade etmektedir. Oysaki Batı demokrasilerinde gittikçe artan ve "aktivist" olarak nitelenen siyasal eylem biçimi de söz konusudur. Özellikle, formal olmayan siyasi davranışlarda bulunmak ya da organizasyonlara katılmak, kadınlar için daha kolay olabilmektedir. Dolayısıyla, siyasi katılım çeşitleri, katılımcı ihtiyaçları açısından farklılaşabilmektedir (Coffe, \& Bolzendahl, 2010, 319).

Siyasi etkinliklere, kadınların erkeklerden farklı biçimlerde ve çoğu zaman daha nadir 
katılımı için pek çok gerekçe sıralanabilir. Bunları dört ana kategoride ele almak mümkündür. Bunlar, en genel hatlarıyla ailevi sorumluluklar, katılım için gerekli eğitim ve beceri noksanlıkları, ayrımcılık ve cinsiyet rolü sosyalleşmesidir (Kart, \& Güldü, 2009, 100). Bütün bunları kapsayan bir şekilde Shvedova (2005) siyasi katılım açısından kadınların karşılaştıkları problemleri "politik, sosyo-ekonomik ve sosyo kültürel" (34) olmak üzere üç ana başlıkta ele alanda ele almaktadir.

Kadınların ve erkeklerin siyasi davranışları arasındaki farklılıkları açıklamak için ileri sürülen çeşitli faktörler söz konusudur ki bunlardan biri sosyo - ekonomik durumdur. Buna göre, toplumsal cinsiyet farklılı̆̆ı, kadınların ve erkeklerin ekonomik açıdan zarar görmelerindeki farklılığın bir sonucu olarak ortaya çıkabilmektedir (Fridkin, \& Kenney, 2007, 134). Örneğin; erkeklerin, kadınlara oranla tam zamanlı işe sahip olması daha muhtemeldir ve iş, siyasi katılım, bilgi ve etki ile pozitif anlamda ilintilidir. Bu nedenle, iş durumunu göz önünde bulundurmak, katılımdaki toplumsal cinsiyet farkının önemli bir kısmını kavramaya aracılık edebilir. (Coffe, \&Bolzendahl, 2010, 319). Benzer şekilde, kadınların, ekonomik kaynaklara ulaşmalarındaki düşük ortalama, onlar için, bir adaylık kampanyası gibi yoğun ve pahalı etkinliklere katılımı zorlaştırmaktadır. Dolayısıyla kadınlar, var olan görece sınırlı kaynaklarını zorlamayacak ve gündelik yaşamlarıyla birleştirebilecekleri daha kolay katılım yolları bulabilmektedirler, eylemin “özel” çeşitleri gibi (Coffe, \& Bolzendahl, 2010, 320). Ennaji (2010) Fas'da, cinsel eşitlik ve kadın özgürlüğü mücadelesinde aktif olan kadınların çoğunluğunun, ailesinin temel ihtiyaçlarını karşılamaya çalışan birçok yoksul kadından farklı olarak rahat bir yaşam süren kadınlar olduğunu ileri sürmektedir.

Siyasi katılımla ilgili olarak, sosyo - ekonomik kaynaklara ulaşma ile katılım arasında doğru bir orantı olduğundan söz edilmiştir. Dolayısıyla buradan hareketle, sosyo - ekonomik statüleri yüksek olan kadınların, siyasi katılımlarının olumlu yönde değiştiği sonucu ortaya çıkmaktadır. Mesleki statü ve işteki tatminin, kadınların siyasi desteği üzerinde pozitif bir etkisi söz konusudur ve çalışan kadınların, çalışmayanlara göre, siyasetle olan ilişkilerini devam ettirme oranı daha yüksektir (Bartolomeo, 2008, 13). Bilim insanları, genel olarak istihdam içinde olanların, özelde de kadınların, siyasi katılımlarını kolaylaştıracak çeşitli fırsatlara erişebildiklerini ileri sürmektedirler. İstihdam içindeki bireyler, para kazanabiliyor, katılım geliştirici iletişimleri ve örgütsel kabiliyetleri uygulayabilme firsatlarına sahip olabiliyor; ek olarak, eğer yöneticilerse, liderlik kapasitelerini geliştirebiliyorlar (Bartolomeo, 2008, 5). Ancak yapılan araştırmalar, endüstrileşmiş toplumlardaki evli ve çalışan kadınların, çalıştıkları işlerin yanında, ev işlerinde de, partnerlerine oranla daha fazla zaman geçirdiğini ortaya koymaktadır. Bu bağlamda kadınların boş zamanlarının çok az olması, siyasi katılımlarını da negatif yönde etkileyebilmektedir (Schlozman, Burns, \& Verba, 1999'dan aktaran, Coffe, \& Bolzendahl, 2010, 321).

Kadın ve erkek arasındaki siyasi davranış bağlamında ortaya çıkan farklıların nedenine yönelik diğer bir yaklaşım da ideolojik temellere işaret etmektedir ki bu da karar almadaki öncelikleri etkilemektedir (Shvedova, 2005, 36). Kadınların, hiyerarşi, otorite ve güç kullanımını reddeden feminist bir ideolojiyi kabul etmeleri, erkeklere göre daha muhtemel olmaktadır. Dolayısıyla bu, kadınların siyasi davranışının ve politik bir takım amaçlar doğrultusunda kendilerini dâhil ettikleri yapılanmaların farklı olması sonucu doğurabilmektedir. Örneğin; feminist kadınlar, askeri müdahaleyi erkeklerden daha az desteklerken sosyal güvenlik, ulusal sağlik, yaşlılık, yiyecek yardımı, çocuk bakımı ve kadınlara yönelik olumlu eylem programları gibi konulara daha fazla destek vermektedirler. Feminist ideoloji, feminist ve feminist olmayan kadınlar arasında da benzer bir farklılaşmaya neden olabilmektedir. Dolayısıyla feminist ideoloji, siyasal görüş ve davranışlardaki toplumsal cinsiyet farklılığının kısmen de olsa açıklanmasına yardımc1 olabilmektedir. (Shvedova, 2005, 36; Fridkin, \& Kenney, 2007, 134).

Diğer bir açıklama, kız ve erkek çocukların ve kadınların ve erkeklerin sosyalizasyon ve deneyimleri bağlamında yapılmaktadır. Kadınların, siyasi ilgi ve bilgi gibi siyasi kaynaklardan 
yoksun olması, toplumsal cinsiyet sosyalleşmesi gibi sosyal süreçlerden kaynaklanıyor olabilir. Erkekler, liderlik, kamusal roller, özerklik ve kendine güven gibi özelliklere yönlendirilirken kadınlar; daha pasif, özel, kural uyumlu ve şefkatli bir toplumsal cinsiyete yönelik sosyalleşmektedir. Bu sosyalizasyonun, kadınların düşük siyasi katılım seviyelerine, siyasi tutumlar ve hayatın erken döneminde başlayan ve bütün yaşam boyunca devam eden katılımlarına etkisi bulunabilir (Coffe, \& Bolzendahl, 2010, 319). Ennaji (2010), Fas'daki kadınların, “evinin kızı ol", "kocanın bakımını üstlen" gibi söylemlerle yetiştirildiğini; kadınlara, kültürel olarak, saflık ve irrasyonellik atfedildiğini ve böylesine bir toplumsallaşma sürecinin onları politik yaşamın kıyısına ittiğini ileri sürmektedir. Gordon'a göre (2008), aileler genellikle oğullarından, kızlarından beklemedikleri bir şekilde, bağımsız ve hatta muhalif olmalarını beklemektedir (34). Gerçekten de ebeveynlik örüntüleri, genç erkeklerin bağımsızlığını ve özerkliğini ve kızların, karşılıklı bağımlılığını ve/veya pasif olmasını desteklemektedir. Chodorow'a göre, cinsiyete dayalı kişilik özellikleri -erkeklerde bağımsızlık, görece duygusuz davranış; kadınlarda ise bağımlılık ve duygusal yoğunluk- insanları toplum ve ekonomi içindeki rollerine hazırlamaktadır (Donovan, 2007, 207). Kız çocuğunun anneyle yaşadığ1 yoğun sevgi ve bağl11ık, onu hem yetişkinlikteki anne rolüne hazırlamakta hem de erkeğe göre daha fazla gelişen bir empati duygusuna neden olmakta ve ilişkilerinde daha şefkatli ve nazik olmalarını da beraberinde getirmektedir. Bütün bunlar, kadınların kişiliğinin derinlerine işlenmesinden ötürü, siyasi davranış ve katılımlarında da farklılığa neden olabilmektedir. Örneğin, dezavantajlı gruplara yönelik kampanyalara katılmak, refah düzeyine yükseltmeye yönelik programlara dahil olmak gibi (Fridkin; Kenney, 2007, 134).

Gordon (2008), sosyal hareket bağlamında, gençlerin siyasi katılımında, aile içindeki toplumsal cinsiyetlendirilmiş dinamiklerin önemine dikkat çekerek, sosyalizasyon sürecinin belirleyiciliğini ortaya koymaktadır. Gordon (2008), çocukların siyasi olarak aktif bireyler olmalarında ailenin merkezi bir rol oynadığını kabul etmektedir. Ancak toplumsal cinsiyet faktörü göz önüne alındığında, aileler ve gençler arasında bu ilişki, karmaşık bir hal almaktadır (34). Gordon (2008), genç aktivistler üzerine yaptığ çalışmasında, özellikle genç kızların ebeveynlerini, kamusal alandaki eylemleri önündeki önemli bir engel olarak algıladıklarını ortaya koymaktadır. Ailelerin erkek çocuklar üzerindeki, kaygı merkezli baskıları daha azken; kız çocuklar üzerindeki baskıları çok daha fazladır. Dolayısıyla bu, kız çocukların, protesto, sokak gösterileri vb. siyasi eylemlere, ideolojik düşüncelerini kamusal alana taşımaları önünde bir engel teşkil etmektedir.

Daha önce ifade edildiği gibi, kadın ve erkek arasındaki siyasi davranış farklılığı, salt kadın ve erkek olmaktan kaynaklanan bir durum değildir. Birçok farklı faktörün, söz konusu kadın ve erkek toplumsal aktörlerde yarattığı etkilerin farklı olması, asıl irdelenmesi gereken konuyu oluşturmaktadır.

Yukarıda ifade edilen faktörlere, din de eklenebilir. Din, bütün toplumlarda var olan, büyük oranda kültürel pratiklerin yapısını belirleyen ve dolayısıyla toplumsal yaşamı şekillendiren bir güce sahiptir. Aydın (2000), dinin birey ve toplumla olan ilişkisini şu şekilde ifade etmektedir:
"Din, insanların (maddi-manevi) çevresini bir algılama sistemidir. Insana hazır bilgiler sunar; nerede ve hangi konumda bulunduğunu işaretleyerek bir kimlik belirler... Din ve toplum, birbirleriyle karşıllklı etkileşim içindedir" (Aydın, 2000, 101).

Buradan hareketle dinin, insanların hayatlarını anlamlandırmak için kullandıkları en önemli referans kaynaklarından biri olduğu ileri sürülebilir. Dolayısıyla din, bireylerin yaşam tarzlarında ve hayattaki seçimlerinde son derece büyük bir etkiye sahiptir. Berger ve Luckmann, din ve toplum arasında çok sıkı bir bağ olduğunu, her toplumun kendi dünyasını ve kendi anlam sistemini oluşturduğunu ve dolayısıyla her toplumun zorunlu olarak dini olduğunu ifade etmek- 
tedir (Thompson, 2004, 21 'den aktaran Güçlü, 2005, 253).

$\mathrm{Bu}$ bilgiler 1şığında dinin, bireylerin siyasi tutum ve davranışlarında etkili olduğu ileri sürülebilir. Ancak kadın ve erkek bireyler üzerinde bu etki, farklı çıktılarla sonuçlanabilmektedir. Dindarlık ve dinle olan yakın ilişki, siyasi katılım bağlamında, kadınlara oranla erkekler için daha fazla söz konusu olabilmektedir. Kadınların dindar olmaları ve dine olan yatkınlıkları erkeklere oranla fazladır ancak dinin erkekler üzerindeki, dindarlarsa eğer, etkisi daha büyük olmaktadır. Birleşik Devletler'de yapılan araştırma, kilise ya da camiye katılımın, erkeklerin siyasi katılımları üzerinde daha güçlü pozitif bir etkisi olduğunu ortaya koymaktadır (Coffe, \& Bolzendahl, 2010, 322).

Kadın ve erkek arasındaki siyasi davranış farklılığı bazen sadece basitçe bir 'farklılık' olarak görülebilir. Ancak bu çoğu zaman, genel bir toplumsal cinsiyet eşitsizliğinin sonucu olarak ortaya çıkan, kadının siyasi yaşama katılamaması ya da çekilmesi ise sonuçlanan bir duruma neden olabilmektedir. Shvedova (2005), bu eşitsizliğe dikkat çekerek, politik yaşamın her şeyden önce "erkeksi bir model etrafinda örgütlendiğini, kadın adaylar için parti desteğinin ve finansal desteğin sınırlı olduğunu ve kadınların, erkeklere oranla daha katı standartlara tabi tutulduğunu" (35) ileri sürmektedir.

Birçok araştırmacı, aile içi dinamiklerle, siyasi katılım arasında bir ilişki olduğunu ileri sürmektedir. Kadınlar ve erkekler arasında, ev içi düzenlemelerdeki eşitsizlikler, siyasi güçteki kadın katılımını etkileyebilmektedir. Siyasi yaşama kadın katılımındaki toplumsal cinsiyet eşitsizliğinin muhtemel nedenlerine ilişkin çeşitli araştırmalar vardır... kadınların, özellikle de yüksek pozisyonlarda, politik kurumlar içerisinde çok az temsil edildiğini doğrulayan ampirik çalışmalar söz konusudur (Bartolomeo, 2008, 3). Siyasi bir yapılanma içerisine katıldıklarında kadınlar, erkekler kamusal temsilleri ve politik temasları gerçekleştiriyorken, 'görünmez eller' ya da siyasi köle rolüne indirgenmektedirler. Örneğin, Bir New England kasabasının, Demokratik ve Cumhuriyetçi organizasyonlarında kadınlar iki kat daha fazla çalışmakta ve erkek çalışanlardan üç kat daha fazla politik temaslarda bulunmalarına rağmen dikkat çekmemiş ve ödüllendirilmemişlerdir çünkü liderlik bayraklarını genellikle erkekler tutmaktadır (Parrillo, Stimson, \& Stimson, 1996, 275). Türkiye'de de durumun benzer olduğu ileri sürülebilir. Demokrat Parti Kadın Kolları Genel Başkanı avukat Kahveci (2010), Türkiye'deki kadın nüfusunun yüzde 53'ü geçtiğini ancak Meclis'teki temsil oranlarının yüzde 2'yi geçemediğini ve bu durumun gerek siyasi parti liderleri gerekse demokrasi açısından oldukça sorunlu bir tablo olduğun bildirmektedir. Türkiye İstatistik Kurumu'nun, Türkiye Büyük Millet Meclisi'nden aktırdığı, seçim yılı ve cinsiyete göre milletvekili sayısı ve Meclis’teki temsil oranı verilerine göre ("seçim yll ve cinsiyet", n.d.), 1935 yılından 2007 yılına kadar yapılan seçimlerde kadın ve erkek milletvekili ve dolayısıyla temsil oranları arasında büyük bir fark vardır. Kadınlar 1935 yılında \%4,5'luk bir temsil oranına sahipken 2007 yılında bu oran sadece $\% 9,1$ 'e yükselmiştir. 2011 seçimlerinin remi olmayan sonuçlarına göre 78 kadın ve 472 erkek milletvekili olarak meclise girmiştir (Bianet, "78 Kadın 472 Erkek Vekil Meclis'te", 2011). Kadın ve erkek vekiller arasındaki fark hala açık olsa da kadın temsil oranında ciddi bir artış olmuştur (Tablo bkz.). Belge'nin (2011) aktardığına göre, kadınların meclisteki temsil oranı artsa da bölgesel olarak kadınların siyasete katılımı ve temsili açısından sorunlu bir tablo söz konusudur. Örneğin; 141 milletvekili çıkaran 43 ilden kadın millet vekili çıkmamıştır (Belge, 2011). Bu durum hem doğu hem de batı illeri için geçerlidir. Dolayısıyla kadınların, erkeklere oranla, temsil oranlarının ve siyasete katılımlarının az olmasının, sadece bölgesel nedenlerle değil, siyasi katılımı etkileyen (ya da engelleyen) bir takım bireysel ya da toplumsal faktörlerle ilintili olduğu ileri sürülebilir.

Bazı araştırmacılar, bununla birlikte, kadınların ev içinde eşit olmadıkları müddetçe siyasi yapılanma içerisinde de temsil edilmeyeceklerini ileri sürmektedir (Bartolomeo, 2008, 3). Bu araştırmacılara göre, kadınların siyasi yapılanmalar içerisinde ağır bir şekilde çalışmaları ancak görünmez olmalarının nedeni, geleneksel aile yapısının, siyasi yapılanma içerisine direkt olarak 
aktarılmış olmasıdır. Buna göre erkekler, 'yönetici' ve 'ekmek kazanan' gibi belirli ve sınırlı siyasi ve ailevi işlevlere sahiptir. Fakat kadınlar, tıpkı ailedeki gibi, diğer her şeyi yapan kişilerdir. Sadece boşlukları doldurmaz, bu boşlukları bulmayı ve onlarla, erkekleri rahatsız etmeksizin başa çıkmayı öğrenmektedirler (Parrillo, Stimson, \& Stimson, 1996, 275).

Geleneksel toplumsal cinsiyet rollerine olan kökten bağlılık, kadınların siyasi katılımını olumsuz yönde etkileyen en önemli faktörlerden biridir. Ev içi rollerin kadınlar aleyhine eşitsiz dağılımı, çocuk sayısı ve bakımı gibi işlerin kadının üzerinde olduğu düşüncesi, kadınların politik yaşama katılımları önünde bir engel teşkil etmektedir. Başka bir ifadeyle, ev içi düzenlemelerindeki toplumsal cinsiyet eşitsizliğinden dolayı kadınların boş zamandan yoksun olmaları, birçok kadını her hangi bir karar verme sürecinin dışında tutmaktadır. Bu gibi teorilerin temel varsayımı, sosyal kaynaklar bahşedilmiş insanların siyasette daha aktif olmalarının mümkün olduğu yönündedir (Bartolomeo, 2008, 5) ki bu kaynakların bahşedildiği grup, genellikle erkekler olmaktadır.

Türkiye ölçeğinde kadınların siyasi katılımlarını ve davranışlarını etkileyen faktörleri ortaya çıkarmak üzere, Gönül Birliği Kültür ve Yardımlaşma Derneği tarafından gerçekleştirilen Avrupa Birliği Destekli Kadın Haklarının Korunması ve Geliştirilmesi Projesi'nin (2009) sonuçlarına göre kadınlar, aile sorumlulukları, iş ve meslek yoğunlukları, ekonomik güçlerinin olmayışı, yeterli yönetim bilgi, deneyim ve görüşlerinin olmayışı, "kadının yeri, evidir" yargısı, yeterli destek ve teşvik görmemeleri, siyasetin erkek işi olduğu yargısı, eğitim düzeylerinin yetersizliği ve siyaset işinin kadınların ilgi alanına girmeyişi gibi nedenler, kadınların siyaseti katılımını engellemektedir. Bununla birlikte yapılan araştırmada, genel olarak kadınların siyasete karşı ilgisiz oldukları ve çalışıp çalışmamanın siyasete aktif olarak katılmada fazla etkisinin olmadığ ortaya çıkmıştır. Ancak bunu basit bir şekilde ilgisizliğin bir sonucu olarak değerlendirmek indirgemeci bir bakış olacağından bu ilgisizliğe neden olan değişkenlerin saptanması gerekmektedir. Nitekim görüşülen kadınlar siyaset kurumuna yönelik bir güvensizlik içindedirler ve yeterli ailevi, ekonomik ve siyasi parti desteğinin siyasi katılımlarını olumlu yönde etkileyeceğini ileri sürmüşlerdir (Gönül Birliği Kültür ve Yardımlaşma Derneği, 2009).

\section{Sonuç}

Siyasi katılım ve toplumsal cinsiyet temelinde, kadın ve erkekler arasındaki siyasi davranış farklılıklarını tartışmak için görüldüğü gibi öncelikle siyasi davranışın ne olduğunu tanımlamak gerekmektedir. Günümüzün gelişen enformatik teknolojileriyle eş zamanlı olarak, katılım ve etkileşim platformlarının çeşitlenmesiyle birlikte anlaşılmaktadır ki siyasi katılım basit bir biçimde, oy verme ya da bir partiye üye olmak gibi, geleneksel tanımlamalarla kavramsallaştırılamamaktadır. Artık gerek kadın gerek erkek olsun bireyler, siyasi düşüncelerini bir takım ekonomik ve politik amaçlar doğrultusunda ifade edecek çok çeşitli yollara başvurabilmektedirler. Dolayısıyla siyasi katılımı ya da davranışı geleneksel bir perspektiften tanımlamak, kadınların siyasi davranışlarını gözden kaçırmaya neden olabilir.

Kadınların siyasi davranışlarını erkeklerinkinden farklılaştıran bir takım faktörler söz konusudur. Ancak bu faktörler sadece siyasi katılım ve davranıştaki farklılara neden olmamakta bir takım faktörlerin kendisi gene bir toplumsal cinsiyet eşitsizliği temelinde yükselmektedir. Dolayısıyla siyasi tutum ve davranış üzerindeki faktörlerin davranışları basit bir biçimde farklılaştığı mı yoksa kadın ve erkek arasındaki asimetrik olarak tanımlanan ilişkiyi sürekli mi kıldığ 1 göz önünde bulundurulması gereken bir noktadır. Kadınlar ve erkekler arasında, siyasi davranış bağlamındaki farklılıklar ve eşitsizlikler genel olarak, sosyo-ekonomik faktörler, geleneksel toplumsal cinsiyet rollerine olan bağlılık ve sosyalizasyon ile açıklanmaya çalışılmaktadır. Kadınların, erkeklere oranla, sosyo-ekonomik kaynaklara ulaşmaları daha zor olmaktadır ve bu durum, onların siyasi katılım ve davranışlarını sınırlandırmaktadır. Bununla birlikte, kadınların ve erkeklerin çocukluk dönemlerindeki sosyalizasyon süreçleri, kadınların aleyhine 
olan bir farklılık sergilemektedir. Erkekler, daha kendine güvenli ve bağımsız yetiştirilirken kadınlar; bağımlı, pasif ve daha duygusal olmaları yönünde bir sosyalizasyon süreci geçirmektedir. Dolayısıyla bu özellikler, kadın ve erkeklerin siyasi davranış ve katılımlarını etkilemektedir. Söz konusu sosyalizasyon süreci ile yakından ilintili olan diğer bir faktör olan geleneksel toplumsal cinsiyet rollerine olan bağlılık, yine kadınların siyasi katılımını olumsuz yönde etkilemektedir. Kamusal ve özel alan ayrımı, özel alan düzenlemeleri içindeki kadın - erkek eşitsizliği ve bu eşitsiz yapının siyasi platforma taşınması, sorunun merkezini teşkil etmektedir.

Kadınların ve erkeklerin siyasi katılım ve davranışları farklılık gösterebilir. Ancak önemli olan nokta, daha önce de ifade edildiği gibi, bu farklılıkların eşitsizlikten ve kadın - erkek arasındaki asimetrik yapılanmadan ileri gelmesidir. Bu asimetrik yapılanma, kadınların hareket alanını daraltmakta ve temsil sorununu ortaya çıkarmaktadır. Dolayısıyla, atılması gereken adımlar öncelikli olarak toplumsal cinsiyet eşitsizliğini önlemeye yönelik olması gerekmektedir. $\mathrm{Bu}$ bağlamda, siyasi partilerin, sivil toplum kuruluşlarının ve diğer ekonomik ve politik örgütlenmelerin bu konuda bilinçli hareket etmeleri son derece önemlidir.

Tablo: Seçim yılı ve cinsiyete göre milletvekili sayısı ve Meclis’teki temsil oranı, 1935 - 2011.

\begin{tabular}{|l|c|c|c|c|c|}
\hline Seçim y1lı & Milletvekili sayıs1 & Erkek & Temsil oranı (\%) & Kadın & Temsil oran1 (\%) \\
\hline 1935 & 399 & 381 & 95,5 & 18 & 4,5 \\
\hline 1939 & 429 & 413 & 96,3 & 16 & 3,7 \\
\hline 1943 & 455 & 439 & 96,5 & 16 & 3,5 \\
\hline 1946 & 465 & 456 & 98,1 & 9 & 1,9 \\
\hline 1950 & 487 & 484 & 99,4 & 3 & 0,6 \\
\hline 1954 & 541 & 537 & 99,3 & 4 & 0,7 \\
\hline 1957 & 610 & 602 & 98,7 & 8 & 1,3 \\
\hline 1961 & 450 & 447 & 99,3 & 3 & 0,7 \\
\hline 1965 & 450 & 442 & 98,2 & 8 & 1,8 \\
\hline 1969 & 450 & 445 & 98,9 & 5 & 1,1 \\
\hline 1973 & 450 & 444 & 98,7 & 6 & 1,3 \\
\hline 1977 & 450 & 446 & 99,1 & 4 & 0,9 \\
\hline 1983 & 399 & 387 & 97,0 & 12 & 3,0 \\
\hline 1987 & 450 & 444 & 98,7 & 6 & 1,3 \\
\hline 1991 & 450 & 442 & 98,2 & 8 & 1,8 \\
\hline 1995 & 550 & 537 & 97,6 & 13 & 2,4 \\
\hline 1999 & 550 & 527 & 95,8 & 23 & 4,2 \\
\hline 2002 & 550 & 526 & 95,6 & 24 & 4,4 \\
\hline 2007 & 550 & 500 & 90,9 & 50 & 9,1 \\
\hline $2011^{1}$ & 550 & 472 & 85,8 & 78 & 14,1 \\
\hline
\end{tabular}

\footnotetext{
${ }^{1} 2011$ seçimlerine ait sonuçlar, resmi olmayan verilere dayanmaktadır.
} 


\section{KAYNAKÇA}

Arat, F. Z. (1998). Kemalizm ve Türk Kadını. A. B. Hacımirzaoğlu (Ed.), 75 Yılda Kadınlar ve Erkekler (s. 51-70). İstanbul: Tarih Vakfi Yayınları.

Aydın, M. (2000). Kurumlar Sosyolojisi. Ankara: Vadi Yayınları.

Bartolomeo D. A. (2008). Gender inequality and female political participation in Great Britain. Department of Communication, Working Paper, 45, 1-14. http://wp.comunite.it/data/wp_no_45_2008.pdf'den erişilmiştir.

Belge, B. (2011, Haziran 13). 43 İlde141 Erkek, 0 (Sifır) Kadın Milletvekili. Bianet. http://bianet.org/ bianet/siyaset/130707-43-ilde-141-erkek-0-sifir-kadin-milletvekili'den erişilmiştir.

Bianet. (2011). 78 Kadın 472 Erkek Vekil Meclis'te. http://bianet.org/bianet/siyaset/130697-78-kadin472-erkek-vekil-mecliste'den erişilmiştir.

Coffe, H., \& Bolzendahl, C. (2010). Same Game Different Rules? Gender Differences in Political Participation. Sex Roles, 62,318-333.

Donovan, J. (2007). Feminist Teori. İstanbul: İletişim Yayınları.

Ennaji, M. (2010). Multiculturalism, gender and political participation in Morocco. Diogenes, 225, 46-57. doi: 10.1177/0392192110374247.

Fridkin L. K., \& Kenny J. P. (2007). Examining the Gender Gap in Children Attitudes Toward Politics. Sex Roles, 56, 133-140.

Gönül Birliği Kültür ve Yardımlaşma Derneği. (2009). Avrupa Birliği Destekli Kadın Haklarının Korunması ve Geliştirilmesi Projesi. http://gonulbirligidernegi.org/yeni_sayfa_2.htm'den erişilmiştir.

Gordon R. H. (2008). Gendered paths to teenage political participation: parental power, civic mobility, and youth activism. Gender \& Society, 22(1), 31-55.

Güçlü, S. (2005). Din Kurumu. İç. S. Güçlü (Ed.), Kurumlara Sosyolojik Bakış (s. 249-281). İstanbul: Birey Yayınları.

Kahveci, D. A. (2010, Aralık 5). Kadınların TBMM'deki temsil oranı utandırıyor. Haber Hürriyeti. http://www.haberhurriyeti.com/HaberDetay/27016-tbmm'deki-kadin-orani-utandiriyor.aspx'den erişilmiştir.

Kart, E. M., \& Güldü, Ö. (2009). Toplumsal Cinsiyet Rolleri ve Siyasal Tutumlar: Sosyal Psikolojik Bir Değerlendirme. Ankara Üniversitesi Siyasal Bilgiler Fakültesi Dergisi, 64(3), 97-116.

Koyuncuoğlu, T. (1998). Medeni Kanun ve Kadın Hakları. İç. A. B. Hacımirzaoğlu (Ed.), 75 Yılda Kadınlar ve Erkekler (58-63). İstanbul: Tarih Vakfı Yayınları.

Parrillo N. V., Stimson, J., \& A. (1996). Comtemporary social problems. United States of America: Allyn and Bacon Publication.

Ranaboldo, C., \& Solana, Y. (2008). Gender inequality in women's political participation in Latin America and the Caribbean, Rural Territorial Dynamics Program. Santiago. http://idl-bnc.idrc.ca/dspace/bitstream/10625/39811/1/128598.pdf' den erişilmiştir.

Sarıbay Y. A. (1994). Siyasal Sosyoloji. İstanbul: Der Yayınlar1.

Shvedova, N. (2005). Obstacles to women's participation in parliament. İç. J. Ballington, \& A. Karam (Ed.), Women in parliament: Beyond numbers (pp. 33-50). Sweden: Trydells Tryckeri AB.

Türkiye İstatistik Kurumu. (Tarih yok). Seçim yılı ve cinsiyete göre milletvekili saylsl ve Meclis'deki temsil oranı, 1935 - 2007. http://www.tuik.gov.tr/PreIstatistikTablo.do?istab_id=198'den erişilmiştir. 